f orest research was subdivided. Each officer had a small clerical staff allotted. In 1929 the staff had expanded until the Institute now employs thirty-five gazetted officers, two hundred and twenty assistants and subordinates, and three hundred and fifty men on daily labour. It is this great development which necessitated the construction of the great buildings opened by the Viceroy on Nov. 7.

In 1906 no special accommodation was available. The first large building was erected at Chand Bagh and opened in 1914. It was confidently expected that this building would suffice for all possible requirements of the Institute for a number of years to come. The development of the forest resources of India made such strides during the War that the Industrial Commission pointed out in 1918 the necessity of expanding the Institute to meet the rapidly increasing demands of the country. The Commissioners advocated the increase of the number of research officers and stated that the equipment provided was entirely inadequate. These recommendations were accepted by both the Government of India and the Secretary of State, and, in spite of later suggestions for cutting down the scale of the new proposals, they survived the ordeal. The workshops of the economic branch were completed and in working order in 1924 and the main building was occupied during the years 1926 and 1928 . The total cost of the new establishments is close upon one million pounds.

The three most handsome rooms in the Forest Research Institute are the new library, in Andamans padauk, the large hall, all Burma teak, and the entrance hall, shisham and rosewood. Another room which is very effective is the office of the forest economist, which is panelled in poon (Calophyllum) from Madras. The other rooms are not so decorative, but, as Burma teak of good quality has been used throughout; they are mostly handsome as well as useful. A special feature has been made of the windows, with good lighting for laboratory work. There are six museums, with floor space of 26,000 square feet, and the ordinary rooms designed for laboratories and offices cover about 63,000 square feet.

In the grounds, besides the workshops of the economic branch are offices for the different branches and numerous residences of all kinds for the staff.

As at first arranged, the buildings at Chand Bagh were to be utilised as the training centre for the Indian probationers for the Indian Forest Service, whose two years' course of training in forestry is now being given at Dehra Dun. It was perhaps too much to hope to keep Chand Bagh in the Department, even though so much forest history has grown up around it. The beautiful building is to be given up and it is to be utilised in the future for medical research work; while part of the new Institute building will be devoted to the educational requirements of the Indian Forest Service probationers.

The chief value of this commemoration number of the Indian Forester, for the future, will not be confined to the account of the opening proceedings of the new buildings. For the latter is followed by a valuable detailed account of the past history and development of the various branches of the Institute from the date of its inauguration in 1906.

\title{
Archæology from the Air in Central America.
}

$\mathrm{T}^{\mathrm{H}}$ HE definitive account of the recent archæological reconnaissance by air in Central Arnerica, to which reference has already been made in our columns (see Nature, Dec. 28, 1929, p. 995), appears in the April number of the Geographical Review (New York). The authors are Mr. Oliver J. Ricketson and Dr. A. V. Kidder, who acted as observers. The text is illustrated by a number of photographs taken by $\mathrm{Mr}$. Ricketson and Mrs. Lindbergh. As previously noted, the leader of the expedition was Col. Lindbergh, who originally suggested the idea of the reconnaissance to the Smithsonian and Carnegie Institutions.

To enable their readers to appreciate the significance of the observations on the four flights which were made, the authors recapitulate the main divisions and distribution of the remains of ancient Maya civilisation. The oldest remains are found at Peten in Guatemala, whence the city-building activities of the Maya were carried to what is now British Honduras and Yucatan. The classic period of the Old Empire, lasting from about the beginning of the Christian era to 610 , was followed by a migration to lands of which northern Yucatan became the most important. There a renaissance took place in the eleventh and twelfth centuries which is marked by the magnificent buildings of Uxmal and Chichen Itzá. Later, the Mexicanisation of Maya art and religion, after the calling in of the Nahua tribes, led to a time of vigorous growth and building activity followed by a hundred years of decadence which ended with the Spanish conquest.

A great deal of the country which was thus occupied is still unexplored. Short of cutting a way through the almost impenetrable bush, the only means of access are the paths of the chichle gatherers (chichle is the sap which forms the basis of chewing gum): Although these paths are gradually opening up the country, they still do not join, and the country lying between is unknown. As travel by bush path gives no opportunity for topographical observation, the general aspect, geographical features, and contour of the Maya country are not known. As became apparent from the observations made on these flights, the existing maps are untrustworthy as regards the situation of natural features, existing settlements, towns, and ruins. Several unmapped natural features were recorded for the first time.

The flights began on Oct. 6, 1929, and a flight was made on each subsequent day up to and including Oct. 10. On the last day, however, comparatively little time was spent in archæological observation, as the party flew to Havana and Miami. The flights were usually at an altitude of 500 feet, as this was found the best for observation, and the average speed was 85 miles per hour. The difficulties of observation owing to the density of the vegetation will be appreciated from the fact that on several occasions the aeroplane circled and recrossed known sites without the observers being able to 'spot' the ruins. It was desired to follow the great causeway which runs for at least fifteen miles from Coba, but although the exact spot at which it leaves the city was known, it could not be found.

The flight on Oct. 6 was from Belize to Merida, a

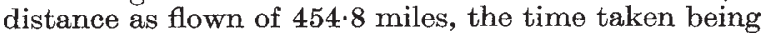
$5 \mathrm{hr} .21 \mathrm{~min}$. Owing to the inexperience of the observers, observation on this flight was found diff. cult; but as time went on rapidity and accuracy were found to come with experience. After spending the night at Merida, the party returned to Belize on Oct. 7 by a slightly shorter route, ending with a flight along the coast, the distance covered being 373 miles in $4 \mathrm{hr} .23 \mathrm{~min}$. On this flight, Chichen Itzá and Yaxuna were visited and a landing made at Lake Payegua. On Oct. 8 a flight was made to Flores, the return being by the southward of the Cockscomb range. On this journey Yaxha, where a landing was

No. 3156, VoL. 125] 
made, Nakun, Tikal Lake, Peten, and Peten Forest were visited-443 miles in $5 \mathrm{hr} .14 \mathrm{~min}$. flying. The flight of Oct. 9 to Cozumel, which occupied $5 \mathrm{hr}$. flying time, was archæologically the most productive. Not only did the party fly over sites already known, such as Tzibanché, an Old Empire site discovered by Dr. Gann in 1927, but on several occasions ruins, pyramids, and buildings were sighted which were entirely unknown before. Of these one was of considerable size. After a night at Cozumel, flight was resumed to Coba, and thence, as previously stated, to Havana and Miami.

In summing up the results of the experiment, the authors express their opinion of the great advantages of the exploration of this country by air. There is obviously an immense advantage to be gained in time. In twenty-one hours of archæological flying, they covered about 1780 miles. The time it would have taken to cover the same country on the ground is incalculable. Some areas could not have been reached at all, while others could have been reached only by a large and expensively equipped expedition. Not only, therefore, does this method of exploration make possible geographical and topographical observation otherwise impossible, but the advantage in time to the excavator if a practical method of organising transport could be devised would be an enormous gain. Both the authors and Col. Lindbergh are convinced that an air survey of the region is both feasible and desirable. It is estimated that a complete survey would oceupy about five months. Col. Lindbergh is prepared to give every assistance in his power towards carrying out this project. In the interests of American archæology, it is to be hoped that a generous benefactor may be found to finance the undertaking.

\section{University and Educational Intelligence.}

OxFORD.- The proposal to use the money set free by the sale of the present site of the Radcliffe $\mathrm{Ob}$ servatory for establishing an observatory in South Africa is advocated by the Savilian professor of astronomy, Prof. H. H. Turner. The grounds on which the plan commends itself to astronomers are stated by him to be chiefly two : first, the extreme uncertainty of the Oxford climate, together with the facilities which now exist for rapid communication; and secondly, the importance of supplying fresh centres of observation in the southern hemisphere, where much work will have to be done to catch up with that already carried out for the northern skies. The disappearance of the old Radcliffe Observatory will be regretted on sentimental grounds, but there would appear to be no question of the scientific advantages to be gained by the present proposal of the trustees.

Applications for grants from the Dixon Fund for scientific research must reach the Academic Registrar of the University of London, South Kensington, S.W.7, by May 15.

Grants from the Thomas Smythe Hughes and Beaverbrook medical research funds of the University of London will shortly be made. Applications should reach the Academic Registrar of the University, South Kensington, S.W.7, by June 15.

SENIOR industrial bursaries for assistance in practical training in engineering are being offered by the Company of Armourers and Brasiers and applications for them should be sent before May 31 to the Clerk of the Company, Armourers' Hall, 81 Coleman Street, E.C.2.

No. 3156, VoL. 125]

\section{Historic Natural Events.}

April 27, I682. Thames Flood.-Under this date, Viscountess Campden wrote to her daughter, the Countess of Rutland: "Never was such flodds known as has bine here, howses drowned and pore children drowne in theare cradels swimen up Fleet Bridge, and there taken up, and tables and hogeds full of beare and all washed away, and peoppele geting up to theare lofts and hole heards of hogs drowned; and so Roger Pratt comeing from Norfolke narely escaped drownding and logers in Fleet Dich drowned, that never such a flood was known, that it is impossable for me to returne till the watters falls".

April 27, 1894. Earthquake in North-east Greece. -A week earlier, on April 20, a strong earthquake occurred in north-east Greece, by which 224 persons were killed and houses were damaged over an area of 1760 sq. miles. The earthquake of April 27 was much stronger, houses being overthrown within an area of $3000 \mathrm{sq}$. miles. With this earthquake, crust-movements occurred along a fault, about 35 miles long, running in a constant west-north-west direction parallel to the Gulf of Euboea. The Plain of Atalante, on the north-east side of the fault, was shifted slightly to the north-west, and depressed by an amount, usually small, but in places by as much as 5 feet.

April 29, I697. Thunderstorm.-A violent thunderstorm occurred over Snowdon and in north-west England, accompanied by hail, over a tract two miles wide and sixty miles long. Hailstones weighed five ounces, and broke nearly all the windows, killed many fowl, poultry, and sheep, and destroyed the green corn.

April 29, I882. Gale.-During the progress of a deep cyclonic system north-eastwards across England, a gale occurred which was unusually severe for so late in the spring. The gale blew from south-west and west, and was general over the south and east of England and the north of France. Much damage was done to the young spring foliage, the leaves being in many cases completely blackened, as though singed by fire. This effect was probably due to mechanical injury caused by the high wind, but was attributed by some observers to the action of sea-salt, crystals of which were clearly traceable upon many of the leaves.

April 29, I892. "Malartic" Cyclone.-A very violent tropical cyclone struck Mauritius, the centre passing directly over Port Louis, where an enormous amount of damage was done. An interesting feature was the overthrow of "Malartic" monument, a column 49 feet high built of stone blocks. The upper part of this column, $26 \frac{1}{2}$ feet high, and 5 feet 3 inches across at the base, was overthrown by the wind, and it was afterwards calculated that the wind pressure to achieve this must have reached $142 \mathrm{lb}$. per square foot, equivalent to a velocity of more than 200 miles per hour. The highest wind velocity recorded at the Pamplemousses Observatory was 123 miles per hour.

April 30, I575. Frost and Flood.-Holinshed records that "all the lochs, rivers, and all manner of other waters were frozen in Scotland, from the beginning of November till the latter end of April, and when the frost brake and the snows melted, there was such a flood flowing over all the plains even to the roots of the mountains as the like had not been seen. Furthermore, when the same shrunk and went away, in the mud and slime there was such a sort of frogs left that when they were dead and began to putrefy the air was so infected that many deadly diseases 